\title{
Synthetic Phosphoantigens Enhance Human Vy9V82 T Lymphocytes Killing of Non-Hodgkin's B Lymphoma
}

\author{
Hélène Sicard, ${ }^{1}$ Talal Al Saati, ${ }^{2}$ Georges Delsol, ${ }^{2}$ and Jean-Jacques Fournié ${ }^{1}$ \\ ${ }^{1}$ INSERM U395, Réponse Immunitaire et CMH, CHU Purpan, Toulouse, France \\ ${ }^{2}$ Laboratoire d'Anatomie et de Pathologie, CHU Purpan, Toulouse, France \\ Accepted April 2, 2001
}

\begin{abstract}
Background: Non-Hodgkin's B lymphomas (NHL) are often resistant to conventional treatments and, until now, immunotherapeutic approaches against NHL only aimed at inducing $\alpha \beta$ anti-tumor effectors. Nevertheless, human blood $\mathrm{V} \gamma 9 \mathrm{~V} \delta 2 \mathrm{~T}$ lymphocytes represent an abundant pool of cytotoxic tumor-reactive cells. $\mathrm{V} \gamma 9 \mathrm{~V} \delta 2 \mathrm{~T}$ cells are strongly activated by natural compounds, from which powerful synthetic ligands have been derived. These synthetic antigens induce efficient $\mathrm{V} \gamma 9 \mathrm{~V} \delta 2 \mathrm{~T}$ cell responses in vitro. Materials and Methods: We set up a series of $\mathrm{V} \gamma 9 \mathrm{~V} \delta 2$ $\mathrm{T}$ cell-activation experiments, including cytotoxic activity and amplification from whole blood cells. Several types of V $\gamma 9 \mathrm{~V} \delta 2$ effectors were challenged against a panel of $16 \mathrm{~B}$ lymphoma cell lines. These tests have been performed in the absence and presence of $\gamma \delta$-specific synthetic ligands to evaluate the effect of such molecules on $\gamma \delta$ anti-tumor activity.
\end{abstract}

Results: We report here that $\mathrm{V} \gamma 9 \mathrm{~V} \delta 2 \mathrm{~T}$ cells recognize B lymphomas. This recognition is associated with the cytotoxic activity against B-lymphoma cells and/or proliferative responses, and appears to be T-cell antigen receptor (TCR)-dependent. Because few B lymphoma induce a complete set of $\mathrm{V} \gamma 9 \mathrm{~V} \delta 2$ cell responses, a chemical ligand of $\mathrm{V} \gamma 9 \mathrm{~V} \delta 2 \mathrm{~T}$ cells was used to enhance both proliferation and cytotoxic activity of anti-B lymphoma effectors. We show that such synthetic compound improves $\mathrm{V} \gamma \mathbf{9} \mathrm{V} \delta 2$ CTL numbers and lysis of B lymphoma lines, especially when the targets are already spontaneously recognized by these effectors.

Conclusions: We report here that human $\mathrm{V} \gamma 9 \mathrm{~V} \delta 2 \mathrm{~T}$ cells anti-B lymphoma response can be improved by use of specific synthetic ligands, which enhance their cytotoxic activity and allows their rapid expansion ex vivo.

\section{Introduction}

Non-Hodgkin lymphomas (NHL) are lymphoproliferative disorders developing from $\mathrm{B}, \mathrm{T}$, or, rarely, natural killer (NK) cells. B cell NHL arise from the clonal expansion of a B cell developmentally blocked at virtually any stage of maturation (1). Increasing evidence suggests that a significant proportion of NHL B cells remain resistant to conventional chemotherapy (2-7). Despite their frequent infiltration by $\mathrm{CD}^{+}$and $\mathrm{CD}^{+}$T cells, B cell NHL rarely induce clinically significant T-cell-mediated responses $(8-10)$. Clinical data suggest that it is partly due to the low frequency of tumor-infiltrating lymphocytes (TILs) and to their insufficient activated state in vivo [for a recent review see Schultze (11)]. Hence, autologous cytotoxic anti-NHL-specific T lymphocytes can be generated and expanded in vitro solely under very specific conditions, requiring cytokine-enriched media $(12,13)$. However, such effectors do not always acquire significant anti-tumor cytotoxic activity (14). Because use of animal models has demonstrated the essential role of $\mathrm{T}$ cells in tumor rejection, most recent immunotherapeutic approaches aim at

Address correspondence and reprint requests to: Hélène Sicard, INSERM U395, Réponse Immunitaire et CMH, CHU Purpan, BP3028, 31024 Toulouse, France. Phone: 335627483 68; fax: 335657483 86; e-mail: hsicard@purpan.inserm.fr improving the in vivo activation of cytotoxic CD8 ${ }^{+}$ $\mathrm{T}$ lymphocytes (CTL) [for a review see Schultze and Nadler (15)]. Vaccination with B-cell NHL-associated isotype (the tumor's most specific antigenic determinant) is one of the most studied strategies so far (16-20). Unfortunately, despite significant improvement, this approach still often shows uneven and unconvincing clinical efficacy (21).

Therefore, there is an obvious need for characterizing CTL populations with anti-tumor activity against B-cell NHL, as well as for defining simple approaches to amplify such anti-NHL-specific effectors.

In healthy human adult blood, around 3\% of $\mathrm{T}$ cells express a $\gamma \delta \mathrm{T}$ cell receptor (TCR), the vast majority of which is of the $\mathrm{V} \gamma 9 \mathrm{~V} \delta 2$ subtype [for a review see De Libero (22)]. $\mathrm{V} \gamma 9 \mathrm{~V} \delta 2 \mathrm{~T}$ lymphocytes are known to accumulate preferentially at the sites of bacterial and parasitic infections (23-28) and are involved in anti-tumor control (29-34). On one hand, in infectious contexts, $\mathrm{V} \gamma 9 \mathrm{~V} \delta 2 \mathrm{~T}$ cells ligands are small protease-resistant phosphorylated molecules, termed "phosphoantigens" (27,35-37). Knowledge of the phosphoantigenic reactivity of $\mathrm{V} \gamma 9 \mathrm{~V} \delta 2 \mathrm{~T}$ cells has significantly improved in recent years [for recent reviews see Halary et al. (38), Belmant et al. (39), and Morita et al. (40)] and aided in the development of powerful synthetic phosphoantigens (41). On the other hand, $\mathrm{V} \gamma 9 \mathrm{~V} \delta 2 \mathrm{~T}$ lymphocytes exert two types of anti-tumor 
activity. First, the broad antigen-specific recognition of hematopoietic tumors by $\mathrm{V} \gamma 9 \mathrm{~V} \delta 2 \mathrm{~T}$ lymphocytes results in cytotoxic activity, inducing Thl cytokine production and proliferation $(32,42)$. Classical $\mathrm{V} \gamma 9 \mathrm{~V} \delta 2$ specific targets are the plasmocytoma RPMI8226 (43) and the Burkitt's lymphoma Daudi $(29,44-46)$, but so far, few if any other B-cell NHL have been described as targets of these CTL. Second, like NK cells, $\mathrm{V} \gamma 9 \mathrm{~V} \delta 2$ $\mathrm{T}$ lymphocytes exert a cytotoxic activity controlled at the effector level by expression of killer Ig-like receptors (KIR) [for a review see Moretta et al. (47)], which interact with major histocompatibility complex (MHC) class I molecules at the surface of the target $(32,48,49)$. Hence, tumor cell lines lacking expression of MHC-class I molecules, like chronic myelogenous leukemia K562 $(29,45,50,51)$ or Burkitt's lymphoma Daudi $(45,48)$, are sensitive to this NK-like cytolytic activity. Despite such promising features, whether human $\mathrm{V} \gamma 9 \mathrm{~V} \delta 2$ CTL act as effectors of an anti-tumor response against B-cell NHL is unknown.

In this study, we questioned the ability of synthetic phosphoantigens to improve the anti-B lymphoma activity of $\mathrm{V} \gamma 9 \mathrm{~V} \delta 2 \mathrm{~T}$ effectors. We provide evidence that $\gamma \delta$-specific synthetic ligands could constitute an efficient and convenient tool to enhance the anti-B lymphoma response of human $\mathrm{V} \gamma 9 \mathrm{~V} \delta 2$ $T$ cells to be tested in future immunotherapeutic approaches.

\section{Materials and Methods}

Tumor Cell Lines

All tumor cell lines were grown in Iscove's Modified Dulbecco's Medium (Biochrom KG, Berlin, Germany) supplemented with $100 \mathrm{U} / \mathrm{ml}$ penicillin/streptomycin, $2 \mathrm{mM}$ glutamine, and $1 \mathrm{mM}$ Na-pyruvate (complete medium), plus $20 \%$ heatinactivated certified fetal calf serum (FCS) (Life Technologies, Paisley, Scotland), except Daudi, K562, RPMI8226, Jurkat, Raji, BL9, HLY-1, and REC1, which were grown in RPMI 1640-glutamax-1 (Life Technologies) medium supplemented with $100 \mathrm{U} / \mathrm{ml}$ penicillin/streptomycin and $1 \mathrm{mM} \mathrm{Na-}$ pyruvate plus $20 \%$ certified FCS (Life Technologies) and cell line DG75, which was grown in Dulbecco's MEM [glutamax-1 medium supplemented with $100 \mathrm{U} / \mathrm{ml}$ penicillin/streptomycin and $1 \mathrm{mM}$ Na-pyruvate plus $20 \%$ certified FCS (Life Technologies)]. Important features of each cell line of this study are listed in Table 1.

Purification of Peripheral Blood Mononuclear Cells (PBMC) Peripheral blood mononuclear cells (PBMC) were prepared from blood from healthy volunteers by centrifugation on Ficoll-Hypaque (Amersham Pharmacia Biotech, Uppsala, Sweden) according to the manufacturer's instructions.

Table 1. Summary of characteristics of the tumor B-Cell lines involved in this study

\begin{tabular}{|c|c|c|c|c|c|}
\hline $\begin{array}{l}\text { Maturation } \\
\text { Stage }\end{array}$ & $\begin{array}{c}\text { Cell } \\
\text { Lines }\end{array}$ & $\begin{array}{l}\text { Main Cytogenetic } \\
\text { Abnormalities }\end{array}$ & $\begin{array}{l}\text { EBV } \\
\text { Status }\end{array}$ & Description & Reference \\
\hline \multirow[t]{6}{*}{ pre-GC } & RECl & $\mathrm{t}(11 ; 14)$ & - & Mantle cell NHL & (87) \\
\hline & OCI-Ly 8 & $\mathrm{t}(14 ; 18)$ & - & DLC (CB/LB) NHL & $(88)$ \\
\hline & DEAU & & - & DLC (CB) NHL & (89) \\
\hline & VAL & $\mathrm{t}(8 ; 14 ; 18) \& \mathrm{t}(3 ; 4)$ & - & DLC (CB) NHL & (90) \\
\hline & LIB & & - & DLC (IB) NHL & * \\
\hline & HLY-1 & $t(3 ; 5)$ & - & (IB) NHL & $(91)$ \\
\hline GC & $\mathrm{RL}$ & $\mathrm{t}(14 ; 18)$ & - & DLC NHL & (92) \\
\hline I & MIEUL & & - & Burkitt's like NHL & $*$ \\
\hline \multirow[t]{6}{*}{ post-GC } & DAUDI & $\mathrm{t}(8 ; 14)$ & + & Burkitt's NHL & ATCC\#CCL-2 13 \\
\hline & RAJI & $\mathrm{t}(8 ; 14)$ & + & Burkitt's NHL & $\begin{array}{l}\text { ATCC\#CCL-86 } \\
\text { Gift from G. }\end{array}$ \\
\hline & BL9 & & + & Burkitt's NHL & $\begin{array}{l}\text { Lenoir, UCB, } \\
\text { Lyon, France }\end{array}$ \\
\hline & DG75 & $\mathrm{t}(8 ; 14)$ & - & Burkitt's NHL & $(93)$ \\
\hline & PASC & $\mathrm{t}(8 ; 14)$ & - & Burkitt's NHL & * \\
\hline & L-428 & & - & Hodgkin's disease derived B cell, IgS ${ }^{-}$ & $(94)$ \\
\hline post-GC & $\begin{array}{l}\text { NCI-H } 929 \\
\text { RPMI } 8226\end{array}$ & & - & $\begin{array}{l}\text { Plasmocytoma, IgA-producing } \\
\text { Plasmocytoma, } \lambda \text { light chain-secreting }\end{array}$ & $\begin{array}{l}\text { ATCC\#CRL-9068 } \\
\text { ATCC\#CCL-155 }\end{array}$ \\
\hline (non-B) & K562 & & - & Chronic myelogenous leukemia & ATCC\#CCL-243 \\
\hline (non-B) & JURKAT & & - & T-lymphoblastic lymphoma/leukemia & ATCC\#CRL-8163 \\
\hline
\end{tabular}

${ }^{*}$ Cell lines established in our laboratory.

DLC, diffuse large cell; CB, centroblastic; LB, lymphoblastic; IB, immunoblastic. 


\section{Generation of V V9V82 T Lymphocyte Polyclonal Cell Lines}

PBMC were added, at a final density of 1 to $2.10^{6}$ cells/ml, to RPMI 1640-glutamax-1, 25 mM Hepes supplemented with $10 \mathrm{U} / \mathrm{ml}$ penicillin/streptomycin and $1 \mathrm{mM}$ Na-pyruvate plus $10 \%$ heat-inactivated $\mathrm{AB}$ human serum (HS), with $100 \mathrm{U} / \mathrm{ml}$ recombinant human IL-2 (Sanofi-Synthelabo, Toulouse, France) and purified mycobacterial phosphoantigen 3-formyl l-butyl pyrophosphate (3fbPP) (final concentration $5 \mathrm{nM}$ ). IL-2 was added every 5 days from day 5 at $50 \mathrm{U} / \mathrm{ml}$ final concentration. Between days 15 and 20, cell populations routinely reach over $95 \% \mathrm{~V} \gamma 9^{+}$ $\mathrm{V} \delta 2^{+} \mathrm{CD}^{+}$cells and can be either stored frozen or used as freshly derived polyclonal cell line.

\section{Cell-Mediated Cytotoxic Assay}

$\mathrm{V} \gamma 9 \mathrm{~V} \delta 2 \mathrm{~T}$ cells or PBMC cytotoxic activity was measured by standard 4-hr ${ }^{51} \mathrm{Cr}$ (Na-bichromate, $10 \mathrm{mCi} / \mathrm{ml}, \mathrm{ICN}$ ) release assays in U-bottom 96-well microtiter plates in complete RPMI 1640 plus 5\% heat-inactivated HS. Briefly, $3.10^{3}{ }^{51} \mathrm{Cr}$-labeled targets were mixed with $6.10^{4}(\mathrm{~V} \gamma 9 \mathrm{~V} \delta 2)$ or $3.10^{5}$ (PBMC) effectors (final volume: $100 \mu \mathrm{l}$ ). When necessary, antibodies [antagonist anti-CD95, ZB4; antidelta2, immu389; anti-gamma 9, immu360; antiCD4, 13B8.2; anti-CD8, B9.11; isotype control mouse (m) IgGl 679.1Mc7, Immunotech-BeckmanCouptu, Roissy, France] or agents [EGTA, tetrasodium salt, Sigma, St. Louis, MO, USA; PHD (formerly BrHPP, (41), Innate Pharma, Marseilles, France)] were added, at the indicated final concentrations, in supplementary $50 \mu \mathrm{l}$ medium. Lysis of Jurkat cells by agonist anti-CD95 mAb (CH1 ; isotype control mIgM: GC32, Immunotech) was performed without $\gamma \delta$ effectors. Maximum and spontaneous releases (MR and SR, respectively) were measured after incubation of the targets in medium alone, with half the labeled targets or half the supernatant, respectively. Percent specific lysis is given by (experimental release - SR)/(MR - SR). SR never exceeded $25 \%$ MR. For antibody-blocking experiments, target cells were incubated in HS during labeling to prevent antibody cross-linking by Fc-receptors. When needed, frozen polyclonal $\mathrm{V} \gamma 9 \mathrm{~V} \delta 2 \mathrm{~T}$-cell lines were used as effectors immediately after thawing.

\section{Induction of Surface CD69 Expression}

Freshly prepared $\mathrm{V} \gamma 9 \mathrm{~V} \delta 2 \mathrm{~T}$ cells $\left(10^{6}\right.$; day 17 after 3fbPP amplification) were mixed with BCECFstained and washed tumor cells in $200 \mu$ l complete RPMI 1640 plus $10 \%$ HS, with a $\gamma \delta /$ target ratio of $1 / 5$. As positive control, Phorbol 12-Myristate 13-Acetate (PMA, Sigma) was added at $1 \mu \mathrm{g} / \mathrm{ml}$. After 8-hr incubation, cells were washed in phosphatebuffered saline (PBS) plus $0.5 \mathrm{mM}$ EDTA and stained with PE-conjugated CD69 monoconal antibody (mAb) (TP1.55.3, Immunotech), after gating on viable, BCECF unstained cells.
In Vitro Amplification of $V \gamma 9 V \delta 2 T$ Cells From PBMC

PBMC (5-10.105) were cultured in 48-well microtiter plates, in 1-ml complete RPMI 1640, $100 \mathrm{U} / \mathrm{ml}$ recombinant human IL-2 (Sanofi-Synthelabo) plus $10 \%$ heat-inactivated $\mathrm{AB} \mathrm{HS}$ in the presence of $3 \mathrm{fbPP}(5 \mathrm{nM})$, various final concentrations of PHD (Innate Pharma, Marseilles, France) (as indicated), or with $2.5 .10^{5}$ Mitomycin C-treated (Sigma) and washed tumor cell targets. Fifty to $100 \mathrm{U} / \mathrm{ml}$ IL-2 were added at days 5 and 10, and amplification of $\mathrm{V} \gamma 9 \mathrm{~V} \delta 2 \mathrm{~T}$ cells was measured by fluorescence activated cell sorting (FACS) analysis. Increase in $\mathrm{V} \gamma 9 \mathrm{~V} \delta 2$ T-cell numbers was calculated as:

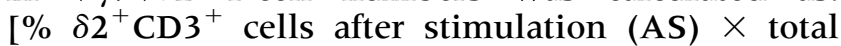
viable cell number AS]/ $\left[\% \delta 2^{+} \mathrm{CD}^{+}\right.$cells before stimulation (BS) $\times$ total viable cell number $\mathrm{BS}]$.

\section{FACS Analysis}

HLA class I surface expression on tumor targets induced CD69 surface expression on $\mathrm{V} \gamma 9 \mathrm{~V} \delta 2 \mathrm{CTL}$ and $\mathrm{V} \gamma 9 \mathrm{~V} \delta 2$ amplification from PBMC were monitored by one- or two-color FACS analysis. Anti-HLA class I mAb W6/32 staining was revealed with fluorescein isothiocyanate (FITC)-conjugated goat anti-mouse (GAM) mAb (Immunotech). FITC-conjugated antiV $\delta 2$ and phycoerythrin (PE)-conjugated anti-CD3 mAbs (immu389 and UCHTl, Immunotech) stain V $\gamma 9 \mathrm{~V} \delta 2$ T cells. PE-conjugated CD69 mAb (TP1.55.3, Immunotech) stains activated $\mathrm{V} \gamma 9 \mathrm{~V} \delta 2 \mathrm{~T}$ cells. The following isotype-matched antibodies were used as controls: mouse (m) IgG2a, U7.27; mIgG1-FITC, mIgGl-PE, 679.1Mc7; mIgG2b-RD1， MOPC-195 (Immunotech). Analyses were performed after gating on viable cells on a Beckman-Coulter apparatus.

\section{Results}

Polyclonal Vy9V82 CTL Kill B Cell NHL Lines In Vitro

The in vitro cytotoxicity of two unrelated primary $\mathrm{V} \gamma 9 \mathrm{~V} \delta 2$ cell lines derived from two different healthy donors was evaluated against 15 non-Hodgkin's B lymphoma cell lines and one Hodgkin's diseasederived B-cell lymphoma line. These B-cell lymphomas were selected such as to represent various stages of B-cell differentiation (see Table 1).

The percentages of specific lysis of each polyclonal $\mathrm{V} \gamma 9 \mathrm{~V} \delta 2$ cells against the panel of NHL are presented in Figure 1. Although overall cytotoxicity of the first polyclonal $\mathrm{V} \gamma 9 \mathrm{~V} \delta 2$ CTL line is reproducibly lower than that of the second, both polyclonal CTL lines exert comparable levels of cytotoxic response against each individual target. For any tested CTL line, the level of spontaneous cytotoxicity is heterogeneous with regard to the target: seven NHL lines are not spontaneously lysed by $\mathrm{V} \gamma \mathbf{9} \mathrm{V} \delta 2 \mathrm{CTL}$ in vitro (below $10 \%$ specific lysis, see Fig. 1, bottom). Six NHL cell lines spontaneously trigger intermediate levels of killing by $\mathrm{V} \gamma 9 \mathrm{~V} \delta 2$ cells $(10-40 \%$ specific lysis: PASC, HLY-1, BL9, RPMI8226, VAL, and DG75) and two NHL lines and the Hodgkin's lymphoma line 


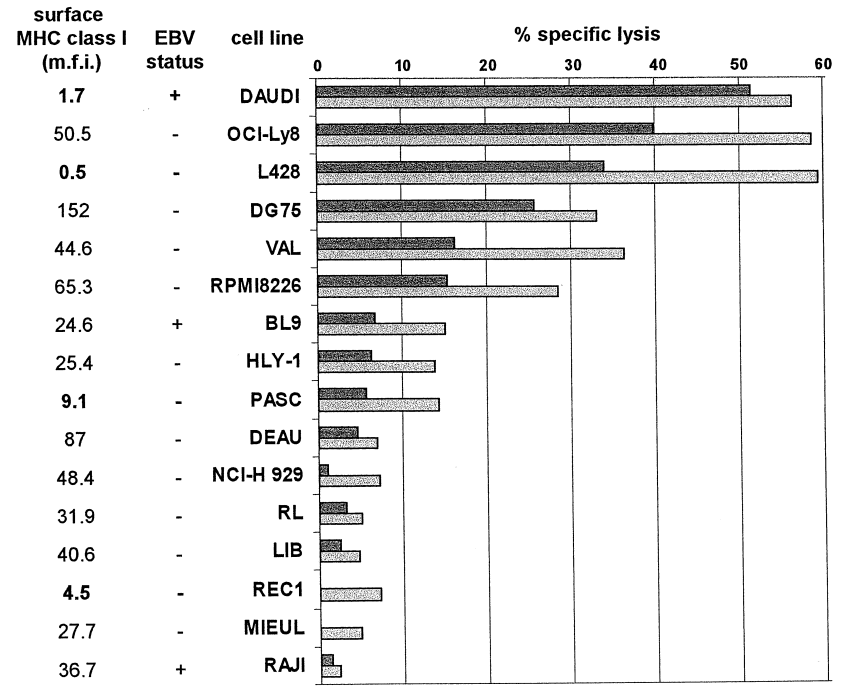

Fig. 1. Spontaneous lysis and HLA-class I expression of NHL B-cell lines by polyclonal $\mathrm{V} \gamma 9 \mathrm{~V} \delta 2 \mathrm{~T}$ lymphocytes. Cytotoxic activity of two independent polyclonal $\mathrm{V} \gamma 9 \mathrm{~V} \delta 2 \mathrm{~T}$ cell lines (cell line 1, dark bars; cell line 2, clear bars) toward 15 NHL B-cell lines and one Hodgkin's lymphoma cell line were tested in vitro. The data represent the average of at least three independent experiments. Polyclonal cytotoxic cell lines were obtained by stimulation of PBMC from healthy donors with mycobacterial phosphoantigen (3fbPP) in the presence of IL-2. After 15 to 20 days, $\mathrm{V} \gamma 9 \mathrm{~V} \delta 2 \mathrm{~T}$ cells account for $90-99 \%$ of the cells. Target cell lines are arbitrarily presented in decreasing order of global (sum of lysis by the two $\mathrm{V} \gamma 9 \mathrm{~V} \delta 2$ cell lines) sensitivity to $\mathrm{V} \gamma 9 \mathrm{~V} \delta 2 \mathrm{CTL}$. $(\mathrm{E} / \mathrm{T}=20 / 1)$. Evaluation of the expression of HLA-class I molecules at the surface of each target is given by the mean fluorescence intensity (MFI) of the whole cell population previously stained with $\mathrm{W} 6 / 32$ and GAM-FITC mAbs. MFI values were obtained by subtracting MFI of the cell population stained with isotypic control IgG2a antibody and GAM-FITC. EBV status is presented according to cell lines referenced in Table 2.

spontaneously activate a high level (above $40 \%$ of specific lysis; Fig. 1, top) of specific lysis by $\gamma \delta$ effectors.

Cytolytic activity of $\mathrm{V} \gamma 9 \mathrm{~V} \delta 2$ CTL for tumor cells is known to be influenced by a deficit in HLA class I molecule expression at the surface of the targets $(32,48,49,52)$, accounting for an NK-like $\gamma \delta$ mediated killing of the HLA-class $\mathrm{I}^{-}$targets $\mathrm{K} 562$ and Daudi $(32,45,50,51)$. To rule out such a possibility, we evaluated the level of surface expression of HLA class I molecules on the target lymphoma lines with the W6/32 mAb directed against HLA-A, $-B,-C,-E$, and -G (Fig. 1). Whereas NHL lines differ in terms of intensity of HLA class I expression, Figure 1 shows that the specific lysis of these targets by $\mathrm{V} \gamma 9 \mathrm{~V} \delta 2$ CTL does not match to their relative deficit in surface expression of HLA class I molecules. The HLA-class $\mathrm{I}^{\text {low }}$ lymphoma RECl and PASC are not killed, whereas several HLA-class I $^{\text {bright }}$ lines (OCI-Ly8, DG75, RPMI8226, and VAL) are efficiently lysed (Fig. 1). Thus, in contrast to K562 and Daudi cell lines, the OCI-Ly8, VAL, DG75, BL9, RPMI8226, and HLY-1 NHL are killed by V $\gamma 9$ V $\delta 2$ CTL solely through a non-NK-like pathway.
Furthermore, $\mathrm{V} \gamma 9 \mathrm{~V} \delta 2 \mathrm{~T}$ cells spontaneous cytotoxicity toward these NHL B cell lines is not specifically restricted to Epstein-Barr Virus (EBV)-positive lymphomas (Fig. 1).

\section{Amplification of Vy9V82 T Cells in Response to B-Cell NHL Lines}

$\mathrm{V} \gamma 9 \mathrm{~V} \delta 2 \mathrm{CTL}$ lymphocytes proliferate in vitro when grown in the presence of some hematopoietic neoplastic cell lines (32), such as the Burkitt's lymphoma Daudi $(29,45)$ and the plasmocytoma RPMI8226 (43). However, V $\gamma 9 \mathrm{~V} \delta 2$ CTL do not proliferate in vitro when grown with their targets of NKlike lysis [e.g., the chronic myelogenous leukemia K562 (32,45)].

Because several B cell lymphoma lines from the above panel activate $\gamma \delta$-selective cytotoxicity, we asked whether these irradiated lymphoma could also induce a selective outgrowth of polyclonal $\mathrm{V} \gamma 9 \mathrm{~V} \delta 2 \mathrm{~T}$ lymphocytes in vitro when co-cultured with freshly purified PBMC from several healthy donors. As expected, Daudi and RPMI8226 cell lines induce expansion of $\mathrm{V} \gamma 9 \mathrm{~V} \delta 2 \mathrm{~T}$ cells from PBMC (Table 2). Similarly, Hodgkin's lymphoma line L428 triggers both high $\mathrm{V} \gamma 9 \mathrm{~V} \delta 2$ lysis and $\mathrm{V} \gamma 9 \mathrm{~V} \delta 2$ CTL expansion from PBMC of two on three donors (Table 2). Interestingly, the NHL line DEAU, which does not induce $\gamma \delta$ cytotoxicity, promotes $\mathrm{V} \gamma 9 \mathrm{~V} \delta 2 \mathrm{~T}$ cell outgrowth from PBMC in two of three donors. None of the other NHL lines tested expand $\mathrm{V} \gamma 9 \mathrm{~V} \delta 2$ CTL from any PBMC tested, although some of them, like OCILy8, DG75, and VAL, trigger strong $\mathrm{V} \gamma 9 \mathrm{~V} \delta 2 \mathrm{~T}$ cell cytotoxic activity. Thus, of several NHL B-cell lines activating $\mathrm{V} \gamma 9 \mathrm{~V} \delta 2 \mathrm{~T}$ cells, few induce both cytotoxicity and amplification responses.

B lymphoma cell lines involved in this study were chosen such as to stretch along the whole B-cell differentiation process (Table 1). This panel comprises B-cell malignancies starting from pregerminal centers (pre-GC) cells, GC/post-GC cells up to immunoglobulin (Ig)-producing cells. Looking for a possible correlate between $\gamma \delta$-activating phenotype and B-cell differentiation, we compared the $\gamma \delta$-stimulating properties of these $16 \mathrm{~B}$ lymphoma and their respective stage of differentiation. This comparison suggested that $\gamma \delta$-activating $\mathrm{B}$ malignancies span all along B-cell maturation.

\section{Specificity of Spontaneous Vy9V82 CTL Cytotoxicity to NHL B-Cell Lines}

The unusual pattern of $\mathrm{V} \gamma 9 \mathrm{~V} \delta 2$ CTL responses when exposed to NHL B-cell lines questioned the nature of the $\mathrm{V} \gamma 9 \mathrm{~V} \delta 2$ activation pathway by NHL. Using OCILy 8 as a model of $\mathrm{V} \gamma 9 \mathrm{~V} \delta 2$ CTL-activating NHL, we investigated some characteristics of its killing pathway and the involvement of the $\mathrm{V} \gamma 9 \mathrm{~V} \delta 2$ TCR. As shown in Figure 1, the HLA-class $I^{\text {bright }}$ OCI-Ly8 NHL is efficiently and spontaneously killed by $\mathrm{V} \gamma 9 \mathrm{~V} \delta 2 \mathrm{~T}$ lymphocytes in vitro but fails to induce $\mathrm{V} \gamma 9 \mathrm{~V} \delta 2 \mathrm{CTL}$ expansion from primary PBMC cultures. 
Table 2. Amplification of $\mathrm{V} \gamma 9 \mathrm{~V} \delta 2 \mathrm{~T}$ cells after incubation with various NHL B-cell lymphoma

V $\gamma 9$ V 82 CTL Expansion from PBMC/

Cell Lines Number of Donors Tested

\begin{tabular}{ll}
\hline DAUDI & $3 / 3$ \\
OCI-Ly8 & $0 / 3$ \\
L428 & $2 / 3$ \\
DG75 & $0 / 2$ \\
VAL & $0 / 3$ \\
RPMI8226 & $3 / 3$ \\
BL9 & $0 / 2$ \\
HLY-1 & $0 / 2$ \\
PASC & $0 / 2$ \\
DEAU & $2 / 3$ \\
NCI-H 929 & $0 / 2$ \\
RL & $0 / 3$ \\
LIB & $0 / 2$ \\
REC1 & $0 / 2$ \\
MIEUL & $0 / 2$ \\
RAJI & $0 / 3$
\end{tabular}

After 13-day co-culture of primary PBMC from healthy donors with irradiated NHL-cells, viable $\mathrm{CD} 3^{+} \mathrm{TCR}-\mathrm{V} \delta 2^{+}$cells were quantified by FACS. Amplification was considered negative when percentage of $\mathrm{CD}^{+}{ }^{+} \mathrm{TCRV} \delta 2^{+}$cells in co-cultures was similar to that of PBMC cultured with IL-2 only. For each NHL, data summarize the ratio of amplification-reactive donors versus number of donors tested. For example, with the stimulating NHL DEAU, representative percentages of $\mathrm{CD} 3^{+} \mathrm{TCRV} \delta 2^{+}$cells are: donor $1,9.9 \%$ in co-culture versus $3.1 \%$ for IL-2 alone; donor 2 , $3.8 \%$ in co-culture versus $2.4 \%$ for IL-2 alone; donor $3,18.1 \%$ in co-culture versus $2.8 \%$ for IL-2 alone. With nonstimulating NHL DG75: representative percentages of $\mathrm{CD} 3^{+} \mathrm{TCRV} \delta 2^{+}$cells are donor $1,2.1 \%$ in co-culture versus $3.1 \%$ for IL-2 alone; donor 2 , $1.1 \%$ in co-culture versus $2.4 \%$ for IL-2 alone.

Although Fas-mediated cytotoxicity is assumed to be negligible in 4 -hr chromium release assay $(53,54)$, we asked whether the strong lysis of OCILy 8 by $\mathrm{V} \gamma 9 \mathrm{~V} \delta 2$ CTL relies on a marked sensitivity of this NHL line to Fas-L. For this purpose, OCI-Ly 8 killing by $\mathrm{V} \gamma 9 \mathrm{~V} \delta 2$ CTL was tested in presence of the Fas-agonist $\mathrm{CH} 1 \mathrm{l}$ mAb (55), which induces the apoptotic death of $\mathrm{Fas}^{+}$-Jurkat cells (Fig. 2A), or conversely in presence of the Fas-antagonist ZB4 $\mathrm{mAb}(56)$, which inhibits $\mathrm{CH} \mathrm{ll}$-induced apoptosis (Fig. 2A). In these experiments, killing of Fas-Daudi or of OCI-Ly 8 by $\mathrm{V} \gamma 9 \mathrm{~V} \delta 2 \mathrm{~T}$ lymphocytes was not altered by the Fas antagonist (Fig. 2A).

Because TCR-mediated activation of CTL usually leads to perforin release [for a review see Shresta et al. (57)], we tested whether OCI-Ly 8 line killing involves the release of perforin by $\mathrm{V} \gamma 9 \mathrm{~V} \delta 2$ $\mathrm{T}$ cells. Although it does not alter the Fas-mediated T-cell cytotoxicity (58), EGTA inhibits the calcium-
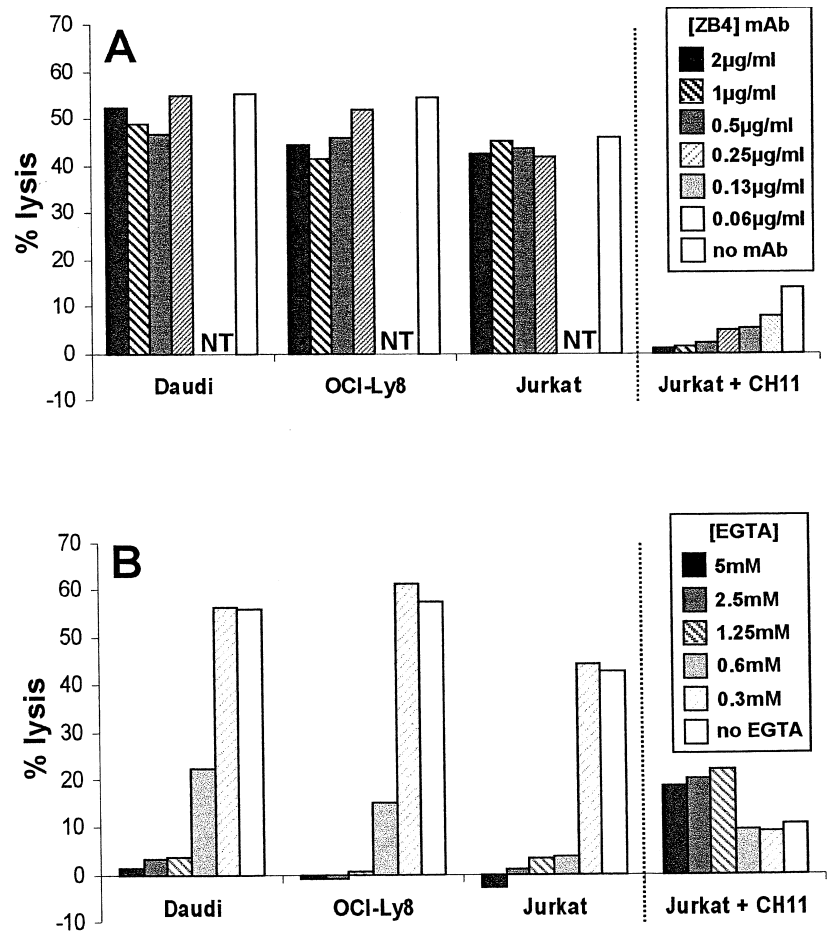

Fig. 2. V $\gamma \mathbf{9} \mathbf{V} \delta 2$ cytotoxicity toward NHL OCI-Ly8. (A) Effect of antagonist anti-Fas ZB4 antibody on $\mathrm{V} \gamma 9 \mathrm{~V} \delta 2$ T-cell cytotoxicity toward Daudi, OCI-Ly8, and Jurkat cells in a 4-hr

${ }^{51}$ chromium release assay. Antagonist effect of ZB4 is demonstrated by its ability to inhibit Fas ${ }^{+}$-Jurkat cells lysis induced in the same conditions by the Fas agonist $\mathrm{CH} 1 \mathrm{l}$ mAb. Isotypematched IgGl antibody has no effect on CH11-induced lysis of Jurkat cells (not shown). ZB4 mAb concentrations are shown in insert box. NT, not tested; $\mathrm{E} / \mathrm{T}=20 / 1$. (B) Effect of $\mathrm{Ca}^{2+}$ chelating agent EGTA on $\mathrm{V} \gamma 9 \mathrm{~V} \delta 2 \mathrm{~T}$-cell cytotoxicity toward Daudi, OCI-Ly 8, and Jurkat cells in a 4-hr ${ }^{51}$ chromium release assay. As a negative control, EGTA effect was also tested on Jurkat cells lysis induced by Fas agonist $\mathrm{CH} 11 \mathrm{mAb}$ in the same conditions. Isotype-matched IgM antibody induced no lysis of Jurkat cells (not shown). EGTA concentrations are shown in insert box. $(E / T=20 / 1)$.

dependent release of perforin (and other soluble mediators) from exocytosis granules. When added to the in vitro mix of OCI-Ly 8 and $\mathrm{V} \gamma 9 \mathrm{~V} \delta 2 \mathrm{CTL}$, EGTA totally suppresses killing of OCI-Ly 8 by $\mathrm{V} \gamma 9 \mathrm{~V} \delta 2 \mathrm{~T}$ cells (Fig. $2 \mathrm{~B}$ ). In contrast to earlier reports $(59,60)$, in our experiments $\mathrm{V} \gamma 9 \mathrm{~V} \delta 2 \mathrm{~T}$ cells kill Jurkat targets in a strictly $\mathrm{Ca}^{2+}$-dependent way (Fig. 2B). EGTA has, however, no effect on the lysis of Jurkat cells induced by the Fas-agonist ( $\mathrm{CH} 1 \mathrm{l}$ $\mathrm{mAb}$, Fig. 2B). Taken together, these results demonstrate that OCI-Ly 8 lysis by $\mathrm{V} \gamma 9 \mathrm{~V} \delta 2 \mathrm{~T}$ lymphocytes results exclusively from a release of granzyme-perforine but not from NHL sensibility to Fas-induced apoptosis, thereby suggesting that OCI-Ly 8 activates $\mathrm{V} \gamma 9 \mathrm{~V} \delta 2 \mathrm{~T}$ lymphocytes in a TCR-dependent fashion.

To address this point more directly, OCI-Ly 8 and $\mathrm{V} \gamma 9 \mathrm{~V} \delta 2$ CTL were co-incubated in the presence of increasing quantities of the anti-TCR V $\delta 2$ mAb Immu389 (61). Figure 3 shows that this 


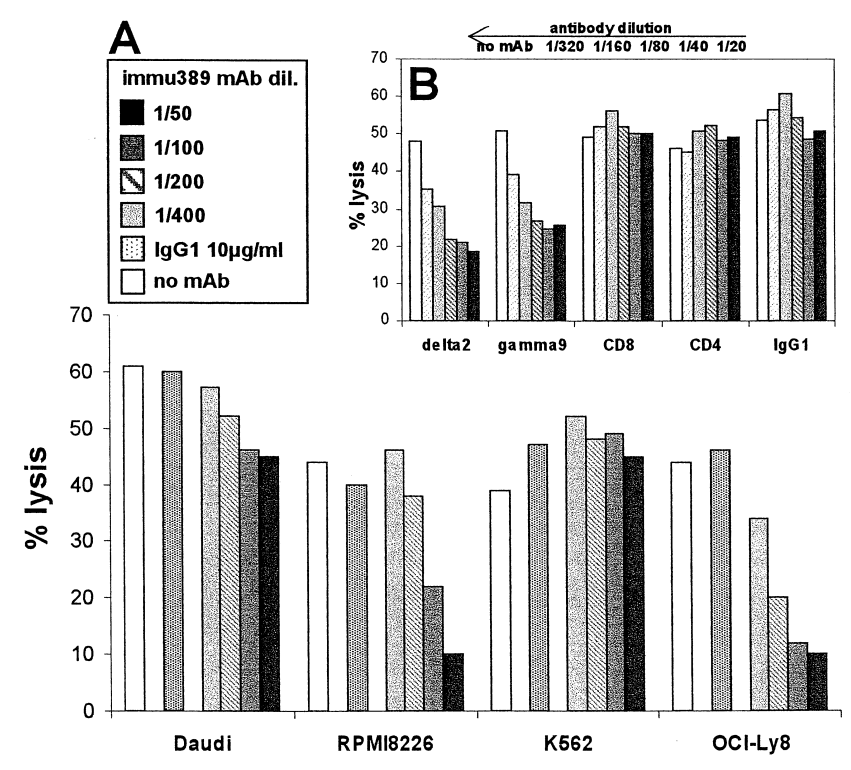

Fig. 3. TCR requirement for $\mathrm{V} \gamma 9 \mathrm{~V} \delta 2$ cytotoxicity toward OCI-Ly8. (A) Effect of increasing concentrations of immu389 anti-delta $2 \mathrm{mAb}$ on $\mathrm{V} \gamma 9 \mathrm{~V} \delta 2 \mathrm{~T}$-cell cytotoxicity toward Daudi, RPMI8226, K562, and OCI-Ly8. Isotypic IgGl (at $10 \mu \mathrm{g} / \mathrm{ml}$ ) antibody was used as a negative control. Immu389 $\mathrm{mAb}$ dilutions are shown in insert box. $(\mathrm{E} / \mathrm{T}=20 / 1)$. (B) Effect of diverse antibodies against CTL surface antigens on polyclonal $\mathrm{V} \gamma 9 \mathrm{~V} \delta 2 \mathrm{~T}$-cell line cytotoxicity toward the follicular lymphoma cell line OCI-Ly8. The four mAb tested share the same isotype (IgGl), shown as negative control. Antibodies dilutions are shown in insert box. $(E / T=20 / 1)$.

antibody strongly blocks lysis of OCI-Ly 8 as well as the target RPMI8226 by polyclonal $\mathrm{V} \gamma 9 \mathrm{~V} \delta 2$ CTL. The anti-TCR V $\delta 2$ mAb only partially inhibits lysis of HLA-class $\mathrm{I}^{-}$Daudi lymphoma, which results both from TCR-mediated and NKlike lysis by $\mathrm{V} \gamma 9 \mathrm{~V} \delta 2 \mathrm{~T}$ cells. As reported $(49,50)$, the anti-TCR V $\delta 2$ mAb Immu389 does not inhibit lysis of HLA-class $\mathrm{I}^{-} \mathrm{K} 562$ tumor cells (Fig. 3A). In line with these results, while mAb directed against TCR $\mathrm{V} \gamma 9$ chains reduces the lysis of OCILy 8 by $\mathrm{V} \gamma 9 \mathrm{~V} \delta 2 \mathrm{~T}$ cells, mAbs against CD 4 and CD 8 seldom expressed on polyclonal $\gamma \delta$ cells have no effect on this lysis (Fig. 3B). Taken together, these results support the idea that the cytotoxicity of $\mathrm{V} \gamma 9 \mathrm{~V} \delta 2$ CTL for NHL target OCI-Ly 8 is mediated by the $\gamma 9 \delta 2$-TCR.

Upon antigen recognition, the TCR mediates initial steps of T-cell activation, ultimately followed by functional T-cell responses. Because $\gamma 9 \delta 2$ TCR-mediated recognition of OCI-Ly8 NHL drives further cytotoxic responses, we asked whether NHL stimulation of $\mathrm{V} \gamma 9 \mathrm{~V} \delta 2$ CTL induces early appearance of activation markers on these effectors. Antigenic activation of $\mathrm{T}$ cells induces the surface expression of specific markers, of which CD69 is one of the earliest [for recent reviews, see Tough $2 \mathrm{t}$ al. (62) and Marzio et al. (63)]. Thus, following exposure to different tumor cell lines, we tested the induction of CD69 at the surface of freshly derived
$\mathrm{V} \gamma 9 \mathrm{~V} \delta 2 \mathrm{~T}$ lymphocytes. As compared to unstimulated $\gamma \delta$ cells alone (negative control, Fig. 4) and PMA-treated $\gamma \delta$ cells (positive control, Fig. 4), Daudi, OCI-Ly8 NHL, or RPMI8226 activate CD69 expression (Fig. 4). Conversely, neither of the $\gamma \delta$ unstimulatory Jurkat and K562 tumor cells do so (Fig. 4). In these experiments, NHL line OCI-Ly 8 induces clear-cut expression of the activation marker CD 69 at the surface of polyclonal $\mathrm{V} \gamma 9 \mathrm{~V} \delta 2 \mathrm{~T}$ lymphocytes as early as $8 \mathrm{hr}$ after co-culture, witnessing early induction by a $\mathrm{V} \gamma 9 \mathrm{~V} \delta 2 \mathrm{TCR}$-mediated activation (Fig. 4).

Taken together, these results demonstrate that although they do not necessarily induce $\gamma \delta$ T-cell proliferation, B lymphoma lines may be specifically

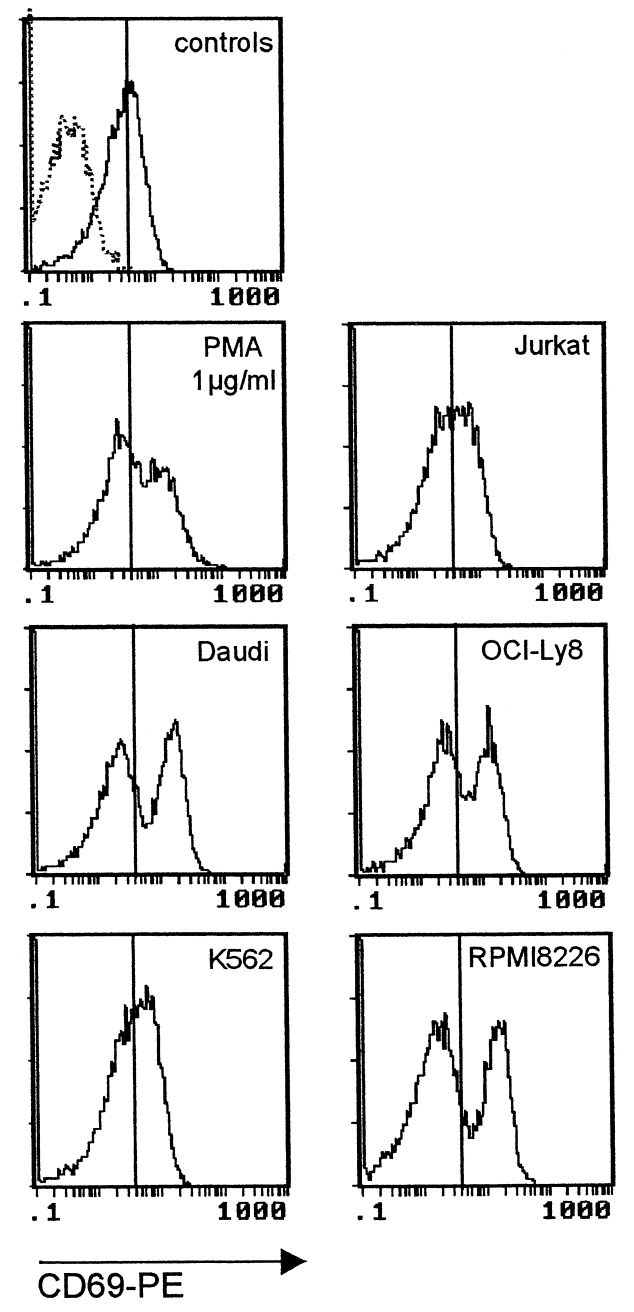

Fig. 4. Expression of the early activation surface marker CD69 by polyclonal $V \gamma 9 \mathrm{~V} \delta 2 \mathrm{~T}$-cell line after exposure to different cells. A freshly derived polyclonal $\mathrm{V} \gamma 9 \mathrm{~V} \delta 2 \mathrm{~T}$ cells population was exposed to several tumor cells in vitro for $8 \mathrm{hr}$. CD69-surface expression on $\mathrm{V} \gamma 9 \mathrm{~V} \delta 2 \mathrm{~T}$ cells was then monitored by FACS analysis. Stimulating lymphoma cells were excluded from analysis by BCECF-staining prior to incubation with the effectors and do not appear here. "Controls" panel shows the staining of $\mathrm{V} \gamma 9 \mathrm{~V} \delta 2 \mathrm{~T}$ cells with IgG2b-RDI isotype antibody (gray line) and with PE-conjugated anti-CD69 antibody after incubation with medium alone. 
recognized by $\mathrm{V} \gamma 9 \mathrm{~V} \delta 2$ TCR and consequently be killed by these effector cells.

\section{Drug-Induced Amplification of V $\gamma 9 V \delta 2$ CTL Cell Numbers and Anti-NHL Cytotoxicity}

Because $\gamma \delta$-stimulating NHL B-cell lines fail to induce a complete set of $\mathrm{V} \gamma 9 \mathrm{~V} \delta 2$ CTL responses in vitro (Fig. 1 and Table 2), this limits the clinical potential of spontaneous activated $\gamma \delta$ cells. However, novel drugs have been recently designed that trigger the complete set of $\mathrm{V} \gamma 9 \mathrm{~V} \delta 2 \mathrm{~T}$ cell responses in vitro (41). This prompted us to test whether such synthetic drugs could circumvent the absence of expansion of these $\gamma \delta$ effectors while maintaining (or enhancing) their anti-NHL cytotoxicity.

To compensate for the absence of amplification of $\mathrm{V} \gamma 9 \mathrm{~V} \delta 2$ effectors in response to target B lymphomas (Table 2), we used synthetic drugs to generate high quantities of anti-B lymphoma $\mathrm{V} \gamma 9 \mathrm{~V} \delta 2 \mathrm{CTL}$ in vitro. These drugs $(39,41)$ specifically mimic natural $\mathrm{V} \gamma 9 \mathrm{~V} \delta 2$-T-cell ligands [referred to as phosphoantigens $(27,35-37,64,65)]$. Increasing concentrations of the drug PHD (41) were added to primary PBMC cultures from four healthy donors (Fig. 5). There was a strong increase in $\mathrm{V} \gamma 9 \mathrm{~V} \delta 2 \mathrm{~T}$-cell numbers from PBMC of all donors, reaching more than 30-fold (Fig. 5A). This amplification is dose dependent, as shown for donor 1 (Fig. 5B). Finally, Figure $5 \mathrm{C}$ shows the maximal percentage of $\mathrm{V} \gamma 9 \mathrm{~V} \delta 2 \mathrm{~T}$ cells obtained for the three other donors.

Thus, although B-lymphoma lines as stimuli may sometimes fail to amplify specific CTL in vitro, these effectors can nevertheless be conveniently amplified in vitro using synthetic drugs. Because some NHL B-cell lines appear resistant to $\mathrm{V} \gamma 9 \mathrm{~V} \delta 2$ CTL lysis in vitro, we also investigated the ability of PHD to improve the cytolytic activity of $\gamma \delta$ effectors. Here, we analyzed the effect of this drug on the cytotoxic activity of two $\mathrm{V} \gamma 9 \mathrm{~V} \delta 2 \mathrm{~T}$-cell lines against the panel of B lymphomas. A final concentration of $20 \mathrm{nM}$ PHD was added in these cytotoxic assays, where the effector-to-target $(\mathrm{E} / \mathrm{T})$ ratio decreases from 20/1 to 2.5/1. Figure 6 shows the effect of PHD added to the anti-NHL cytotoxicity of V $\gamma 9 \mathrm{~V} \delta 2$ CTL. PHD effect on NHL killing by $\gamma \delta$ effectors is heterogeneous, as observed above for their spontaneous anti-NHL cytotoxicity. On the one hand, PHD improves slightly the killing of genuine $\gamma \delta$-activating targets such as Daudi, OCILy8, L428, DG754, or VAL (Fig. 6). On the other hand, PHD does not elicit killing of unstimulatory NHL lines (Raji, MIEUL, LIB, or RECl, Fig. 6). Interestingly, PHD increases by about 10 -fold the anti-NHL cytolytic potential of $\mathrm{V} \gamma 9 \mathrm{~V} \delta 2 \mathrm{CTL}$ against some targets (see lysis of HLY-1, NCI-H 929, and RL in Fig. 6). PHD appears most efficient in enhancing $\mathrm{V} \gamma 9 \mathrm{~V} \delta 2 \mathrm{~T}$-cell cytotoxicity toward partially activating NHL B-cell lines.

Because the PHD-induced increase in $\gamma \delta$ antiNHL activity had only been challenged on long-term
A

$\mathrm{V} \gamma 9 \mathrm{~V} \delta 2 \mathrm{~T}$ cell numbers

(fold increase)

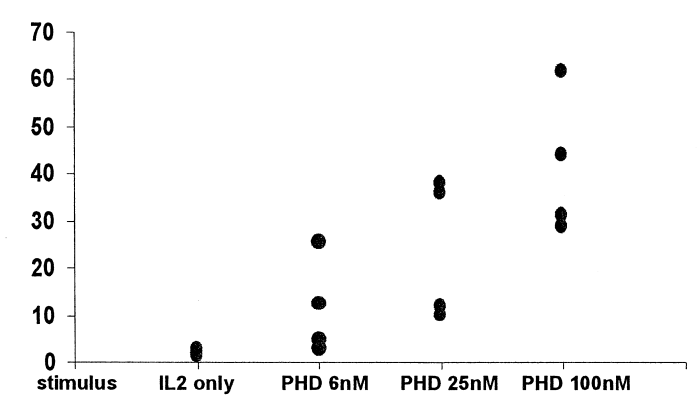

B
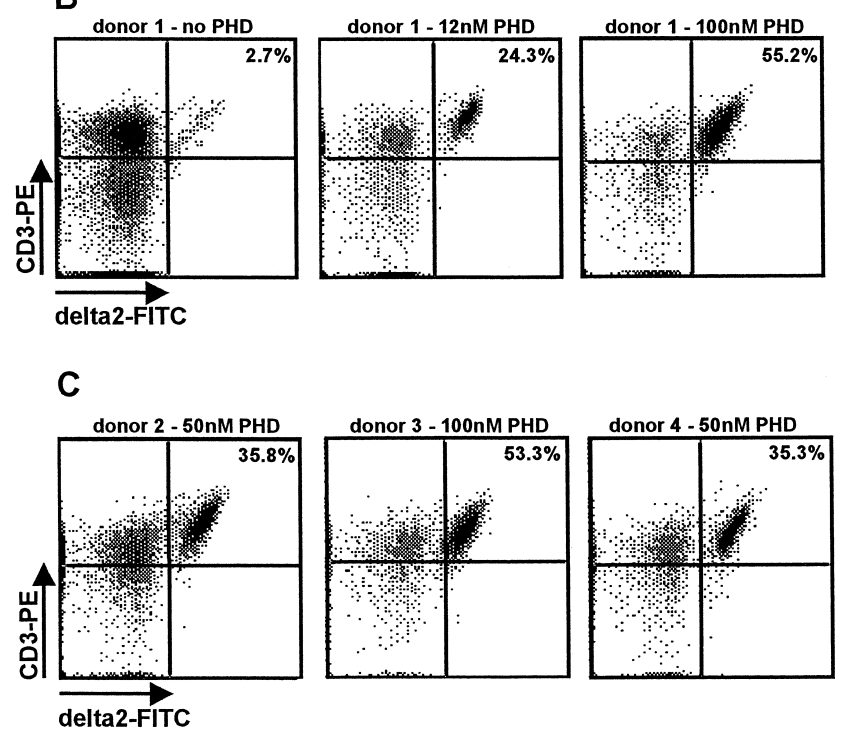

Fig. 5. Amplification of $\mathrm{V} \gamma 9 \mathrm{~V} \delta 2 \mathrm{~T}$ cells with the synthetic phosphoantigen PHD. Amplification of $\mathrm{V} \gamma 9 \mathrm{~V} \delta 2 \mathrm{~T}$ cells among PBMC cultures from four different healthy donors after 12 days of incubation with various concentrations of the synthetic phosphoantigenic $\mathrm{V} \gamma 9 \mathrm{~V} \delta 2$-specific drug PHD, in the presence of IL2 , was monitored by FACS. (A) Increase in number of $\mathrm{V} \gamma \mathbf{9} \mathrm{V} \delta 2$ $\mathrm{T}$ cells after stimulation of PBMC from four donors with three concentrations of PHD and IL-2 alone. The data give the fold increase calculated as follows: [\% $\delta 2^{+} \mathrm{CD}^{+}$cells after stimulation $(\mathrm{AS}) \times$ total viable cell number AS]/[\% $\delta 2^{+} \mathrm{CD}^{+}$cells before stimulation (BS) $\times$ total viable cell number BS]. (B) Dosedependent increase of $\mathrm{V} \gamma 9 \mathrm{~V} \delta 2 \mathrm{~T}$ cells from PBMC of donor 1 after PHD stimulation. Data show the dot-plots of doublestaining FACS analysis from the specified culture conditions. (C) Maximal increase of $\mathrm{V} \gamma 9 \mathrm{~V} \delta 2 \mathrm{~T}$ cells from PBMC of the three other donors after PHD stimulation. Data show the dot-plots of double-staining FACS analysis from the specified culture conditions.

preactivated $\gamma \delta$ primary cell lines, we questioned the relevance of such a bioactivity for B lymphoma targets within freshly drawn $\gamma \delta$ T cells. Thus, the effect of PHD stimulation on anti-NHL V $\gamma 9 \mathrm{~V} \delta 2$ fresh CTL was tested by setting cytotoxicity experiments with freshly prepared PBMC effectors. Primary PBMC from two healthy donors with distinct $\mathrm{V} \gamma 9 \mathrm{~V} \delta 2 \mathrm{~T}$-cell proportions were tested extemporaneously in a 4-hr chromium release assay, for their 

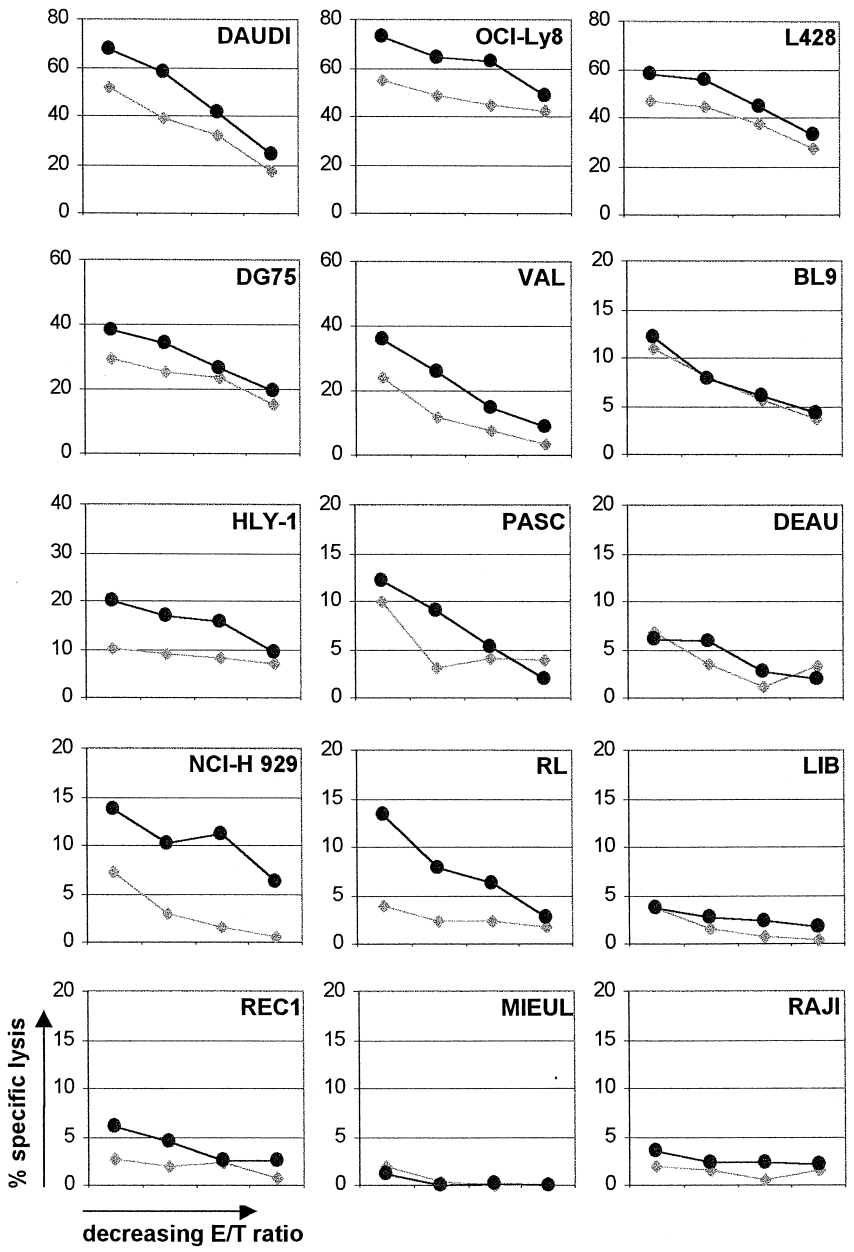

Fig. 6. Effect of PHD on polyclonal $\mathrm{V} \gamma \mathbf{9} \mathrm{V} \delta 2 \mathrm{CTL}$ cytotoxicity toward NHL B-cell lines. Two $\mathrm{V} \gamma 9 \mathrm{~V} \delta 2 \mathrm{~T}$-cell lines were tested for their spontaneous cytotoxic activity toward various NHL B-cell lines (gray diamonds) or when assayed in the presence of $20 \mathrm{nM}$ PHD (black circles), with $\mathrm{E} / \mathrm{T}=20 / \mathrm{l}$; 10/1; 5/1; $2.5 / 1$. Results shown are the mean specific lysis of the two $\mathrm{V} \gamma 9 \mathrm{~V} \delta 2 \mathrm{~T}$-cell lines used in Figure 1.

lysis of the preceding panel of human B lymphomas (Fig. 7). As already observed with long-term polyclonal $\gamma \delta$-cell lines (see Fig. 1), freshly prepared PBMC from the two different donors spontaneously exert anti-NHL cytotoxicity, although of different intensity according to the target. Adding PHD (final concentration 200 and $800 \mathrm{nM}$, without IL-2) to such CTL assays gave roughly a similar pattern of effect as formerly observed using PHD-amplified $\gamma \delta$ effectors (Fig. 7). Killing of genuine B lymphoma targets and of stimulating NHL is significantly improved, with a PHD dose effect (see Daudi, OCI-Ly8, L428, DG75, VAL, BL9, Fig. 7), while resistant NHL remain unaffected (see HLY-1, DEAU, MIEUL and Raji, Fig. 7). In these experiments, the PHD effect was not greatly influenced by the ratio of PHD-reactive V $\gamma 9$ V $\delta 2$ T cells among PBMC (e.g., the VAL NHL line is killed similarly by PHD-treated PBMC from donor 1 and donor 2, Fig. 7). Furthermore, PHD
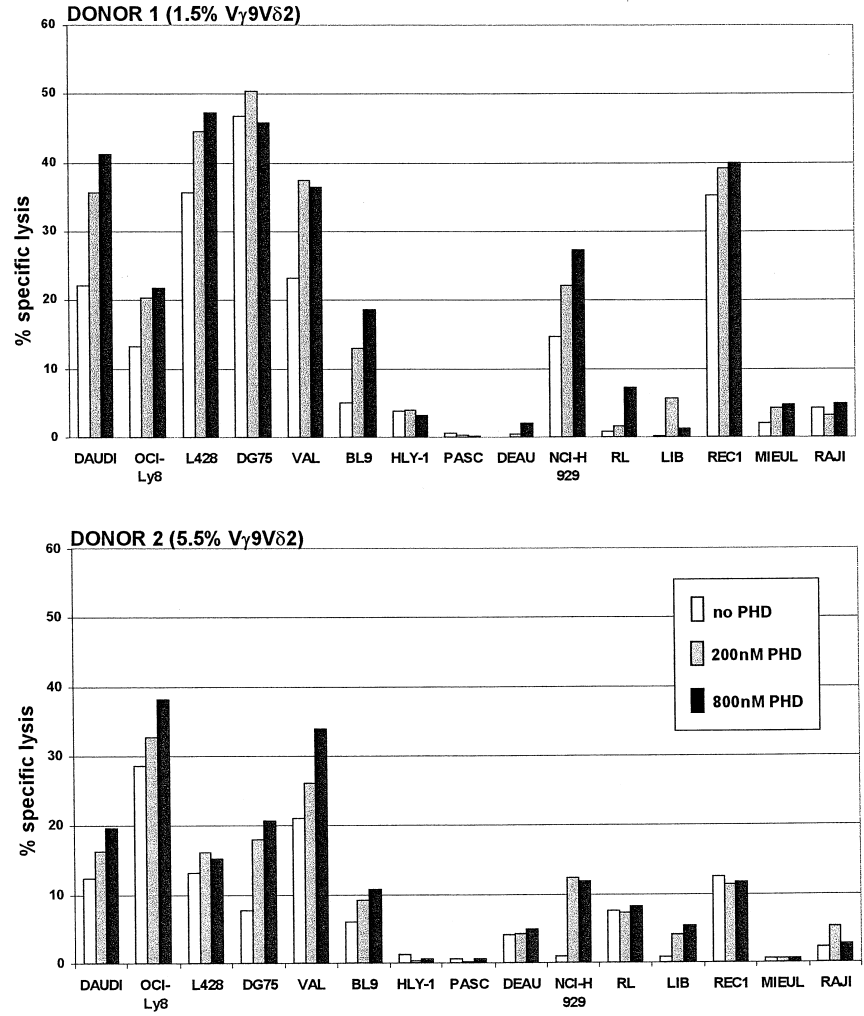

Fig. 7. Effect of PHD on freshly isolated PBMC cytotoxicity toward NHL B-cell lines. Immediately after isolation from two healthy donors (comprising $1.5 \%$ and $5.5 \% \mathrm{~V} \gamma 9 \mathrm{~V} \delta 2 \mathrm{~T}$ cells), PBMC were challenged for their lysis of NHL cell lines in a $4-\mathrm{hr}{ }^{51} \mathrm{Cr}$ release assay in the absence (white bars) or in the presence of two final concentrations of PHD (gray bars, $200 \mathrm{nM}$ PHD; black bars, $800 \mathrm{nM}$ PHD) to test the improvement of their cytotoxic activity. Results show the mean of at least three measures. $(\mathrm{E} / \mathrm{T}=100 / 1)$.

exposure of freshly prepared PBMC induces a low level of killing of some otherwise resistant cell lines (see NCI-H 929, RL or LIB, Fig. 7).

\section{Discussion}

This in vitro study aimed at documenting the cytotoxic potential of human $\mathrm{V} \gamma 9 \mathrm{~V} \delta 2 \mathrm{~T}$ lymphocytes against non-Hodgkin's B-cell lymphoma lines and the ability of $\gamma \delta$ synthetic ligands to improve this anti-B lymphoma activity. We show that this CTL population is spontaneously activated to kill several NHL B-cell lines in vitro. As judged by HLA class I molecule expression at the surface of the targets, this cytotoxicity does not result from an NK-like lysis, but most probably arises from a specific TCR-mediated stimulation. The features of the killing mechanism of the target NHL line OCI-Ly 8 by V $\gamma 9 \mathrm{~V} \delta 2$ CTL confirms their specific activation. Thus, human $\mathrm{V} \gamma 9 \mathrm{~V} \delta 2$ $\mathrm{T}$ cells represent potential anti-NHL CTL, of high frequency among circulating $\mathrm{T}$ cells in blood of healthy donors (approximately 1-10\%) (22).

Nevertheless, the activation of $\mathrm{V} \gamma 9 \mathrm{~V} \delta 2$ CTL by B lymphoma cell lines does not necessarily lead to a 
complete set of T-cell activation phenotypes. The NHL DEAU cell line induces their specific amplification from primary PBMC while failing to activate $\mathrm{V} \gamma 9 \mathrm{~V} \delta 2 \mathrm{~T}$-cell cytotoxicity. Furthermore, only three of nine B lymphoma activating $\mathrm{V} \gamma 9 \mathrm{~V} \delta 2 \mathrm{~T}$-cell cytotoxicities also promote $\mathrm{V} \gamma 9 \mathrm{~V} \delta 2$ CTL expansion. In this respect, it has often been reported that NHL cells hardly stimulate $\alpha \beta$ CTL proliferation in vitro unless expression of several costimulatory molecules is induced at their surface (66-72).

Absence of $\mathrm{V} \gamma 9 \mathrm{~V} \delta 2$ CTL amplification following contact with NHL can be conveniently overcome using drugs specific for the $\gamma \delta$-TCR. Anti-NHL cytotoxic $\mathrm{V} \gamma 9 \mathrm{~V} \delta 2 \mathrm{~T}$ lymphocytes expand upon stimulation with natural phosphoantigens such as $3 \mathrm{fbPP}$ $(35,64)$ or synthetic analogs such as PHD. This amplification requires IL-2 and very low concentrations of the drug PHD (5-50 nM) within 10 days. Moreover, these molecules can also significantly enhance the anti-NHL cytotoxic activity of both polyclonal $\mathrm{V} \gamma 9 \mathrm{~V} \delta 2$ $\mathrm{T}$-cell lines and freshly prepared $\mathrm{V} \gamma 9 \mathrm{~V} \delta 2 \mathrm{~T}$ cells within PBMC. The drug-induced improvement of anti-B lymphoma activity is particularly significant toward targets that otherwise spontaneously induce a low level of $\mathrm{V} \gamma 9 \mathrm{~V} \delta 2 \mathrm{~T}$-cell cytotoxicity. Variable levels of basal B lymphoma lysis by PBMC CTL are observed within donors (Fig. 7). It is assumed that $\mathrm{V} \gamma 9 \mathrm{~V} \delta 2 \mathrm{~T}$ cells account for some of this initial cytotoxicity. However, PHD-dependent increase in B lymphoma lysis is solely mediated by responding $\mathrm{V} \gamma 9 \mathrm{~V} \delta 2$ $T$ cells; natural phosphoantigens and their synthetic counterparts do not stimulate other cellular effectors $(35,41,73)$ (Fig. 5). Interestingly, PHD not only improves the lysis of $\gamma \delta$-sensitive B lymphoma lines, but also confers low cytotoxicity to $\mathrm{V} \gamma 9 \mathrm{~V} \delta 2 \mathrm{CTL}$ toward usually resistant cell lines. Unfortunately, one third of the NHL lines tested are not killed, even by effectors stimulated with their specific ligand. We assume that intrinsic NHL-resistance to granzyme-perforinemediated lysis could account for such resistance.

The panel of B-cell lymphoma involved in this study was chosen because it comprises malignant counterparts of B cells at various stages of differentiation (Table 1). Thus, we questioned the existence of a correlation between the $\gamma \delta$ stimulation property and the level of B-cell target differentiation. However, because $\gamma \delta$-stimulating B cells span all along the different maturation steps, we could not link the $\mathrm{V} \gamma 9 \mathrm{~V} \delta 2 \mathrm{~T}$-cell-stimulating property to the B-cell differentiation stage. This finding is in agreement with the assumed ubiquity of the B lymphoma ligands of $\mathrm{V} \gamma 9 \mathrm{~V} \delta 2 \mathrm{~T}$ cells (32), which remain unknown. Nevertheless, with regard to the nature of these antigens, this study suggests that $\mathrm{V} \gamma 9 \mathrm{~V} \delta 2 \mathrm{tu}-$ mor antigens are most probably not related to (1) maturation-dependent B cell markers, (2) B-cellactivation specific molecules, or (3) B-cell receptor (BCR)-expression and Ig secretion. Thus, one may consider $\mathrm{V} \gamma \mathbf{9} \mathrm{V} \delta 2 \mathrm{CTL}$ as potential effectors of almost any B malignancy.
Immunotherapeutic trials against NHL aim at eliciting specific cytotoxic T-cell responses against these cancer cells (21). Generally, the candidate effectors are $\alpha \beta \mathrm{CD}^{+} \mathrm{T}$ lymphocytes, because they can be manipulated by two distinct approaches. These effectors are either stimulated in vivo after vaccination with a tumor-specific antigenic determinant $(16,17,19,20)$ or they are expanded ex vivo as CTL against the autologous tumor $(12,13,69)$. The first approach has improved through monitoring the acquired immunity and a better detection of the residual disease. Nevertheless, vaccination still requires further improvement for its generalization in anti-lymphoma protection (21). More specifically, cancer vaccination would benefit from the identification of novel specific tumor antigens (74). Ex vivo generation of specific autologous CTL has proven difficult for the relatively low TILs frequency, their poor intrinsic cytotoxic activity, and their sophisticated culture conditions $(12,13,69,75,76)$. Therefore, a need for the identification of novel effectors of the anti-lymphoma immune response still remains. This study supports new options for the design of antitumor cellular immunotherapies. As yet, however, no report describes autologous $\mathrm{V} \gamma 9 \mathrm{~V} \delta 2 \mathrm{~T}$ lymphocytes as NHL-TILs in vivo $(77,78)$ or as CTL amplified in vitro from TILs (13); our study indicates that reactive $\mathrm{V} \gamma 9 \mathrm{~V} \delta 2$ CTL against $\mathrm{B}$ lymphomas can be readily generated in vitro. In this context, human $\mathrm{V} \gamma 9 \mathrm{~V} \delta 2 \mathrm{~T}$ lymphocytes offer several advantages as cellular effectors as compared to $\alpha \beta$ cytotoxic T cells. Above all, whereas the usual frequency in blood of almost any $\alpha \beta$ CTL is below $0.01 \%$, that of $\mathrm{V} \gamma 9 \mathrm{~V} \delta 2$ CTL is quite higher, being $1-10 \%$ in adults (22). Furthermore, polyclonal $\mathrm{V} \gamma 9 \mathrm{~V} \delta 2 \mathrm{CTL}$ cell lines expand within a few days after stimulation of PBMC with specific ligands $(35,36,51)$ (Fig. 5). As effectors of innate immunity, $\mathrm{V} \gamma 9 \mathrm{~V} \delta 2 \mathrm{~T}$ lymphocytes acquire cytotoxic activity against tumor target without former exposure (79), whereas alloreactive $\mathrm{CD}^{+} \mathrm{CTL}$ have to be primed to become efficient responders to NHL cells $(12,66,68,70)$. Furthermore, once generated from PBMC through phosphoantigenic stimulation, $\mathrm{V} \gamma 9 \mathrm{~V} \delta 2 \mathrm{~T}$ lymphocytes simultaneously acquire responsiveness to several distinct target cells $(34,50,79)$ (this study). Thus, generating autologous activated $\gamma \delta$ T cells is far simpler than expanding $\alpha \beta$ CTL against NHL cells in the presence of the patient's tumor cells $(12,13)$. Finally, the recent development of chemical ligands for $\mathrm{V} \gamma 9 \mathrm{~V} \delta 2 \mathrm{~T}$ cells even reinforces their interest for the design of future antilymphoma immunotherapeutic tests. The synthesis of chemical ligands is easier and less expensive than the purification of natural phosphoantigens from microbial sources. Moreover, for obvious safety reasons, the use of synthetic ligands is easier to control than that of extracts from pathogens such as $M$. tuberculosis.

Another advantage of the $\mathrm{V} \gamma \mathbf{9} \mathrm{V} \delta 2$ CTL population is that its reactivity and functionality is not MHC restricted $(29,41,44,79-81)$. On the other hand, 
weak $\alpha \beta$ T-cell response against $\mathrm{B}$ lymphoma is partly due to the poor antigen-presenting cell (APC) function of the tumor cells $(66,70,82)$. Hence, $\mathrm{V} \gamma 9 \mathrm{~V} \delta 2$ CTL are interesting effectors because their cytotoxic response does not depend on a classical presentation of tumor antigens, also circumventing the need for improving ex vivo the APC function of dendritic cells with tumor antigens (83-86). In conclusion, this study suggests that the $\mathrm{V} \gamma 9 \mathrm{~V} \delta 2$ population of CTL should be considered as a potential pool of anti-NHL effectors, for which novel powerful stimulating drugs are now available.

\section{Acknowledgments}

We thank J. Boyes for expert technical assistance on NHL cell culture, Ph. Lebouteiller for generous gift of W6/32 mAb, G. Cassar for Cell Sorting facility (IFR30), Sanofi-Synthelabo (Toulouse, France) for generous gift of recombinant human IL-2, and F. Meggetto and L. Astudillo-Bordas for fruitful discussions. This work was supported by research funding from INSERM and l'Association pour la Recherche sur le Cancer. H.S., T.A.S., and G.D. are supported by grants from la Ligue Nationale Contre le Cancer.

\section{References}

1. Kuppers R, Klein U, Hansmann ML, Rajewsky K. (1999) Cellular origin of human B-cell lymphomas. N. Engl. J. Med. 341: $1520-1529$.

2. King K, Younes A. (2000) Ifosfamide- and paclitaxel-based treatment of relapsed and refractory lymphoma. Semin. Oncol. 27: 14-22.

3. Blade J, Kyle RA. (1999) Nonsecretory myeloma, immunoglobulin D myeloma, and plasma cell leukemia. Hematol. Oncol. Clin. North Am. 13: 1259-1272.

4. Soubeyran P, Debled M, Tchen N, et al. (2000) Follicular lymphomas-a review of treatment modalities. Crit. Rev. Oncol. Hematol. 35: 13-32.

5. Davies FE, Anderson KC. (2000) Novel therapeutic targets in multiple myeloma. Eur. J. Haematol. 64: 359-367.

6. Fisher RI. (2000) Diffuse large-cell lymphoma. Ann. Oncol. 11: 29-33.

7. Moskowitz CH. (1998) Conventional treatments for nonHodgkin's lymphoma: the need for new therapies. J. Nucl. Med. 39: 2S-10S.

8. Bonnefoix T, Piccinni MP, Jacob MC, Pegourie B, Sotto JJ. (1989) Limiting dilution analysis of the frequency of IL2 responsive $\mathrm{T}$ cells in lymph nodes involved by $\mathrm{B}$-cell nonHodgkin's lymphomas. Leuk. Res. 13: 323-329.

9. Jacob MC, Piccinni MP, Bonnefoix T, et al. (1990) T lymphocytes from invaded lymph nodes in patients with B-cellderived non-Hodgkin's lymphoma: reactivity toward the malignant clone. Blood 75: 1154-1162.

10. Bonnefoix T, Claret E, Piccinni MP, Jacob MC, Zheng XQ, Sotto JJ. (1991) Impaired clonogenic potential of CD25 positive T cells in lymph nodes involved by B cell non-Hodgkin's lymphomas. Immunol. Lett. 27: 135-139.

11. Schultze JL. (1999) Why do B cell lymphoma fail to elicit clinically sufficient $\mathrm{T}$ cell immune responses? Leuk. Lymphoma 32: 223-236.

12. Schultze JL, Seamon MJ, Michalak S, Gribben JG, Nadler LM. (1997) Autologous tumor infiltrating T cells cytotoxic for follicular lymphoma cells can be expanded in vitro. Blood 89: 3806-3816.
13. Chaperot L, Delfau-Larue MH, Jacob MC, et al. (1999) Differentiation of antitumor-specific cytotoxic $\mathrm{T}$ lymphocytes from autologous tumor infiltrating lymphocytes in nonHodgkin's lymphomas. Exp. Hematol. 27: 1185-1193.

14. Shi I, Bonnefoix T, Heuze-Le Vacon F, et al. (1995) Autotumour reactive T-cell clones among tumour-infiltrating $\mathrm{T}$ lymphocytes in B-cell non-Hodgkin's lymphomas. Br. J. Haematol. 90: $837-843$.

15. Schultze JL, Nadler LM. (1999) T cell mediated immunotherapy for B cell lymphoma. J. Mol. Med. 77: 322-331.

16. Kwak LW, Campbell MJ, Czerwinski DK, Hart S, Miller RA, Levy R. (1992) Induction of immune responses in patients with B-cell lymphoma against the surface-immunoglobulin idiotype expressed by their tumors. N. Engl. J. Med. 327: 12091215.

17. Nelson EL, Li X, Hsu FJ, et al. (1996) Tumor-specific, cytotoxic T-lymphocyte response after idiotype vaccination for B-cell, non-Hodgkin's lymphoma. Blood 88: 580-589.

18. Schultze JL. (1997) Vaccination as immunotherapy for B cell lymphoma. Hematol. Oncol. 15: 129-139.

19. Hsu FJ, Caspar CB, Czerwinski D, et al. (1997) Tumorspecific idiotype vaccines in the treatment of patients with B-cell lymphoma-long-term results of a clinical trial. Blood 89: 3129-3135.

20. Bendandi M, Gocke CD, Kobrin CB, et al. (1999) Complete molecular remissions induced by patient-specific vaccination plus granulocyte-monocyte colony-stimulating factor against lymphoma. Nat. Med. 5: 1171-1177.

21. de Gruijl TD, Curiel DT. (1999) Cancer vaccine strategies get bigger and better. Nat. Med. 5: 1124-1125.

22. De Libero G. (1997) Sentinel function of broadly reactive human $\gamma \delta$ T cells. Immunol. Today 18: 22-26.

23. Janis EM, Kaufmann SH, Schwartz RH, Pardoll DM. (1989) Activation of $\gamma \delta \mathrm{T}$ cells in the primary immune response to Mycobacterium tuberculosis. Science 244: 713-716.

24. Roussilhon C, Agrapart M, Ballet JJ, Bensussan A. (1990) $\mathrm{T}$ lymphocytes bearing the $\gamma \delta \mathrm{T}$ cell receptor in patients with acute Plasmodium falciparum malaria. J. Infect. Dis. 162: 283285.

25. Sumida T, Maeda T, Takahashi H, et al. (1992) Predominant expansion of $\mathrm{V} \gamma 9 \mathrm{~V} \delta 2 \mathrm{~T}$ cells in a tularemia patient. Infect. Immun. 60: 2554-2558.

26. Hara T, Mizuno Y, Takaki K, et al. (1992) Predominant activation and expansion of $\mathrm{V} \gamma 9$-bearing $\gamma \delta \mathrm{T}$ cells in vivo as well as in vitro in Salmonella infection. J. Clin. Invest. 90: 204210.

27. Poquet Y, Kroca M, Halary F, et al. (1998) Expansion of $\mathrm{V} \gamma 9 \mathrm{~V} \delta 2 \mathrm{~T}$ cells is triggered by Francisella tularensis-derived phosphoantigens in tularemia but not after tularemia vaccination. Infect. Immun. 66: 2107-2114.

28. Kroca M, Tarnvik A, Sjostedt A. (2000) The proportion of circulating $\gamma \delta \mathrm{T}$ cells increases after the first week of onset of tularaemia and remains elevated for more than a year. Clin. Exp. Immunol. 120: 280-284.

29. Sturm E, Braakman E, Fisch P, Vreugdenhil RJ, Sondel P, Bolhuis RL. (1990) Human V $\gamma 9 \mathrm{~V} \delta 2$ T cell receptor- $\gamma \delta$ lymphocytes show specificity to Daudi Burkitt's lymphoma cells. J. Immunol. 145: 3202-3208.

30. Malkovska V, Cigel FK, Armstrong N, Storer BE, Hong R. (1992) Antilymphoma activity of human $\gamma \delta$ T-cells in mice with severe combined immune deficiency. Cancer Res. 52: 5610-5616.

31. Malkovska V, Cigel F, Storer BE. (1994) Human T cells in hu-PBL-SCID mice proliferate in response to Daudi lymphoma and confer anti-tumour immunity. Clin. Exp. Immunol. 96: $158-165$.

32. Fisch P, Meuer E, Pende D, et al. (1997) Control of B cell lymphoma recognition via natural killer inhibitory receptors implies a role for human $\mathrm{V} \gamma 9 \mathrm{~V} \delta 2 \mathrm{~T}$ cells in tumor immunity. Eur. J. Immunol. 27: 3368-3379.

33. Fisch P, Moris A, Rammensee HG, Handgretinger R. (2000) Inhibitory MHC class I receptors on $\gamma \delta \mathrm{T}$ cells in tumour immunity and autoimmunity. Immunol. Today 21: 187-191. 
34. Kunzmann V, Bauer E, Feurle J, Tony FW, Wilhelm M. (2000) Stimulation of $\gamma \delta \mathrm{T}$ cells by aminobisphosphonates and induction of antiplasma cell activity in multiple myeloma. Blood 96: 384-392.

35. Constant P, Davodeau F, Peyrat MA, et al. (1994) Stimulation of human $\gamma \delta \mathrm{T}$ cells by nonpeptidic mycobacterial ligands. Science 264: 267-270.

36. Tanaka Y, Morita CT, Nieves E, Brenner MB, Bloom BR. (1995) Natural and synthetic non-peptide antigens recognized by human $\gamma \delta$ T cells. Nature 375: 155-158.

37. Behr C, Poupot R, Peyrat MA, et al. (1996) Plasmodium falciparum stimuli for human $\gamma \delta \mathrm{T}$ cells are related to phosphorylated antigens of mycobacteria. Infect. Immun. 64: 2892-2896.

38. Halary F, Fournie JJ, Bonneville M. (1999) Activation and control of self-reactive $\gamma \delta$ T cells. Microbes Infect. 1: 247-253.

39. Belmant C, Espinosa E, Halary F, et al. (1999) Conventional and non-conventional recognition of non-peptide antigens by T lymphocytes. C. R. Acad. Sci. III 322: 919-924.

40. Morita CT, Lee HK, Leslie DS, Tanaka Y, Bukowski JF, Marker-Hermann E. (1999) Recognition of nonpeptide prenyl pyrophosphate antigens by human $\gamma \delta \mathrm{T}$ cells. Microbes Infect. 1: 175-186.

41. Belmant C, Espinosa E, Halary F, et al. (2000) A chemical basis for recognition of nonpeptide antigens by human $\gamma \delta \mathrm{T}$ cells. FASEB J. 14: 1669-1670. Integral version published online July 24, 2000: 10.1096/fj.99-0909fje

42. Fisch P, Malkovsky M, Braakman E, et al. (1990) $\gamma \delta \mathrm{T}$ cell clones and natural killer cell clones mediate distinct patterns of non-major histocompatibility complex-restricted cytolysis. J. Exp. Med. 171: 1567-1579.

43. Selin LK, Stewart S, Shen C, Mao HQ, Wilkins JA. (1992) Reactivity of $\gamma \delta \mathrm{T}$ cells induced by the tumour cell line RPMI 8226: functional heterogeneity of clonal populations and role of GroEL heat shock proteins. Scand. J. Immunol. 36: 107117.

44. Fisch P, Malkovsky M, Kovats S, et al. (1990) Recognition by human $\mathrm{V} \gamma 9 \mathrm{~V} \delta 2 \mathrm{~T}$ cells of a GroEL homolog on Daudi Burkitt's lymphoma cells. Science 250: 1269-1273.

45. Fisch P, Oettel K, Fudim N, Surfus JE, Malkovsky M, Sondel PM. (1992) MHC-unrestricted cytotoxic and proliferative responses of two distinct human $\gamma \delta \mathrm{T}$ cell subsets to Daudi cells. J. Immunol. 148: 2315-2323.

46. Bukowski JF, Morita CT, Tanaka Y, Bloom BR, Brenner MB, Band H. (1995) V $\gamma 9 \mathrm{~V} \delta 2$ TCR-dependent recognition of nonpeptide antigens and Daudi cells analyzed by TCR gene transfer. J. Immunol. 154: 998-1006.

47. Moretta A, Biassoni R, Bottino C, Mingari MC, Moretta L. (2000) Natural cytotoxicity receptors that trigger human NK-cell-mediated cytolysis. Immunol. Today. 21: 228-234.

48. Halary F, Peyrat MA, Champagne E, et al. (1997) Control of self-reactive cytotoxic $\mathrm{T}$ lymphocytes expressing $\gamma \delta \mathrm{T}$ cell receptors by natural killer inhibitory receptors. Eur. J. Immunol. 27: 2812-2821.

49. Poccia F, Cipriani B, Vendetti S, et al. (1997) CD94/NKG2 inhibitory receptor complex modulates both anti-viral and anti-tumoral responses of polyclonal phosphoantigen-reactive V $\gamma 9 \mathrm{~V} \delta 2$ T lymphocytes. J. Immunol. 159: 6009-6017.

50. Ferrarini M, Heltai S, Toninelli E, Sabbadini MG, Pellicciari C, Manfredi AA. (1995) Daudi lymphoma killing triggers the programmed death of cytotoxic $\mathrm{V} \gamma 9 \mathrm{~V} \delta 2 \mathrm{~T}$ lymphocytes. J. Immunol. 154: 3704-3712.

51. L'Faqihi FE, Guiraud M, Dastugue N, et al. (1999) Acquisition of a stimulatory activity for $\mathrm{V} \gamma 9 \mathrm{~V} \delta 2 \mathrm{~T}$ cells by a Burkitt's lymphoma cell line without loss of HLA class I expression. Hum. Immunol. 60: 928-938.

52. Carena I, Shamshiev A, Donda A, Colonna M, Libero GD. (1997) Major histocompatibility complex class I molecules modulate activation threshold and early signaling of $\mathrm{T}$ cell antigen receptor- $\gamma \delta$ stimulated by nonpeptidic ligands. J. Exp. Med. 186: 1769-1774.

53. Golstein P, Marguet D, Depraetere V. (1995) Fas bridging cell death and cytotoxicity: the reaper connection. Immunol. Rev. 146: $45-56$.
54. Zeine R, Pon R, Ladiwala U, Antel JP, Filion LG, Freedman MS. (1998) Mechanism of $\gamma \delta \mathrm{T}$ cell-induced human oligodendrocyte cytotoxicity: relevance to multiple sclerosis. $J$. Neuroimmunol. 87: 49-61.

55. Berthou C, Michel L, Soulie A, et al. (1997) Acquisition of granzyme $\mathrm{B}$ and Fas ligand proteins by human keratinocytes contributes to epidermal cell defense. J. Immunol. 159: 5293-5300.

56. Estaquier J, Tanaka M, Suda T, Nagata S, Golstein P, Ameisen JC. (1996) Fas-mediated apoptosis of $\mathrm{CD}^{+}$and $\mathrm{CD}^{+}{ }^{+} \mathrm{T}$ cells from human immunodeficiency virus-infected persons: differential in vitro preventive effect of cytokines and protease antagonists. Blood 87: 4959-4966.

57. Shresta S, Pham CT, Thomas DA, Graubert TA, Ley TJ. (1998) How do cytotoxic lymphocytes kill their targets? Curr. Opin. Immunol. 10: 581-587.

58. Rouvier E, Luciani MF, Golstein P. (1993) Fas involvement in $\mathrm{Ca}^{2+}$-independent $\mathrm{T}$ cell-mediated cytotoxicity. J. Exp. Med. 177: 195-200.

59. Peyrat MA, Davodeau F, Houde I, et al. (1995) Repertoire analysis of human peripheral blood lymphocytes using a human V $\delta 3$ region-specific monoclonal antibody. Characterization of dual T cell receptor (TCR) $\delta$-chain expressors and $\alpha \beta$ T cells expressing $\mathrm{V} \delta 3 \mathrm{~J} \alpha \mathrm{C} \alpha$-encoded TCR chains. J. Immunol. 155: 3060-3067.

60. Haeker G, Wagner H. (1994) Proliferative responses of human $\gamma \delta \mathrm{T}$ cells display a distinct specificity pattern. Immunology 81: 564-568.

61. Gan YH, Malkovsky M. (1996) Mechanisms of simian $\gamma \delta$ $\mathrm{T}$ cell cytotoxicity against tumor and immunodeficiency virus-infected cells. Immunol. Lett. 49: 191-196.

62. Tough DF, Sun S, Zhang X, Sprent J. (1999) Stimulation of naive and memory $\mathrm{T}$ cells by cytokines. Immunol. Rev. 170: 39-47.

63. Marzio R, Mauel J, Betz-Corradin S. (1999) CD69 and regulation of the immune function. Immunopharmacol. Immunotoxicol. 21: 565-582.

64. Belmant C, Espinosa E, Poupot R, et al. (1999) 3-Formyl1-butyl pyrophosphate A novel mycobacterial metaboliteactivating human $\gamma \delta$ T cells. J. Biol. Chem. 274: 32079-32084.

65. Jomaa H, Feurle J, Luhs K, et al. (1999) V $\gamma 9 \mathrm{~V} \delta 2 \mathrm{~T}$ cell activation induced by bacterial low molecular mass compounds depends on the 1-deoxy-D-xylulose 5-phosphate pathway of isoprenoid biosynthesis. FEMS Immunol. Med. Microbiol. 25: 371-378.

66. Schultze JL, Cardoso AA, Freeman GJ, et al. (1995) Follicular lymphomas can be induced to present alloantigen efficiently: a conceptual model to improve their tumor immunogenicity [published erratum appears in Proc. Natl. Acad. Sci. U.S.A. (1995) 92: 10818]. Proc. Natl. Acad. Sci. U.S.A. 92: 8200-8204.

67. Plumas J, Chaperot L, Jacob MC, et al. (1995) Malignant B lymphocytes from non-Hodgkin's lymphoma induce allogeneic proliferative and cytotoxic $\mathrm{T}$ cell responses in primary mixed lymphocyte cultures: an important role of co-stimulatory molecules CD80 (B7-1) and CD86 (B7-2) in stimulation by tumor cells. Eur. J. Immunol. 25: 3332-3341.

68. Vyth-Dreese FA, Dellemijn TA, van Oostveen JW, Feltkamp CA, Hekman A. (1995) Functional expression of adhesion receptors and costimulatory molecules by fresh and immortalized B-cell non-Hodgkin's lymphoma cells. Blood 85: 2802-2812.

69. Cardoso AA, Seamon MJ, Afonso HM, et al. (1997) Ex vivo generation of human anti-pre-B leukemia-specific autologous cytolytic T cells. Blood 90: 549-561.

70. Dorfman DM, Schultze JL, Shahsafaei A, et al. (1997) In vivo expression of B7-1 and B7-2 by follicular lymphoma cells can prevent induction of T-cell anergy but is insufficient to induce significant T-cell proliferation. Blood 90: 4297-4306.

71. Schmitter D, Bolliger U, Hallek M, Pichert G. (1999) Involvement of the CD27-CD70 co-stimulatory pathway in allogeneic T-cell response to follicular lymphoma cells. Br. J. Haematol. 106: $64-70$. 
72. Chaperot L, Jacob MC, Molens JP, Manches O, Bensa JC, Plumas J. (2000) From the study of tumor cell immunogenicity to the generation of antitumor cytotoxic cells in nonHodgkin's lymphomas. Leuk. Lymphoma. 38: 247-263.

73. Tanaka Y, Brenner MB, Bloom BR, Morita CT. (1996) Recognition of nonpeptide antigens by T cells. J. Mol. Med. 74: 223-231.

74. Rosenberg SA. (1999) A new era for cancer immunotherapy based on the genes that encode cancer antigens. Immunity 10: 281-287.

75. Perambakam S, Amin K, Naresh K, Advani S, Nadkarni J. (1997) Auto-tumor reactive cytotoxic T-cell responses in B-cell non-Hodgkin's lymphoma. Leuk. Lymphoma. 27: 145152 .

76. Bartik MM, Welker D, Kay NE. (1998) Impairments in immune cell function in B cell chronic lymphocytic leukemia. Semin. Oncol. 25: 27-33.

77. Luna-Fineman S, Lee JE, Wesley PK, Clayberger C, Krensky AM. (1992) Human cytotoxic T-lymphocytes specific for autologous follicular lymphoma recognize immunoglobulin in a major histocompatibility complex restricted fashion. Cancer 70: 2181-2186.

78. Leger-Ravet MB, Devergne O, Peuchmaur M, et al. (1994) In situ detection of activated cytotoxic cells in follicular lymphomas. Am. J. Pathol. 144: 492-499.

79. Lang F, Peyrat MA, Constant P, et al. (1995) Early activation of $\mathrm{V} \gamma 9 \mathrm{~V} \delta 2 \mathrm{~T}$ cell broad cytotoxicity and TNF production by nonpeptidic mycobacterial ligands. J. Immunol. 154: 5986-5994.

80. Holoshitz J, Romzek NC, Jia Y, et al. (1993) MHC-independent presentation of mycobacteria to human $\gamma \delta \mathrm{T}$ cells. Int. Immunol. 5: 1437-1443.

81. Morita CT, Tanaka Y, Bloom BR, Brenner MB. (1996) Direct presentation of non-peptide prenyl pyrophosphate antigens to human $\gamma \delta$ T cells. Res. Immunol. 147: 347-353.

82. Gribben JG, Cardoso AA, Schultze JL, Nadler LM. (1997) Biologic response modifiers in acute lymphoblastic leukemia. Leukemia 11(Suppl 4): S31-S33.

83. Young JW, Inaba K. (1996) Dendritic cells as adjuvants for class I major histocompatibility complex-restricted antitumor immunity. J. Exp. Med. 183: 7-11.

84. Paglia P, Chiodoni C, Rodolfo M, Colombo MP. (1996) Murine dendritic cells loaded in vitro with soluble protein prime cytotoxic $\mathrm{T}$ lymphocytes against tumor antigen in vivo. J. Exp. Med. 183: 317-322.

85. Celluzzi CM, Mayordomo JI, Storkus WJ, Lotze MT, Falo LD, Jr. (1996) Peptide-pulsed dendritic cells induce antigenspecific CTL-mediated protective tumor immunity. J. Exp. Med. 183: 283-287.

86. Hsu FJ, Benike C, Fagnoni F, et al. (1996) Vaccination of patients with B-cell lymphoma using autologous antigenpulsed dendritic cells. Nat. Med. 2: 52-58.

87. Rimokh R, Berger F, Delsol G, et al. (1994) Detection of the chromosomal translocation $\mathrm{t}(11 ; 14)$ by polymerase chain reaction in mantle cell lymphomas. Blood 83: 1871-1875.

88. Berinstein NL, Jamal HH, Kuzniar B, Klock RJ, Reis MD. (1993) Sensitive and reproducible detection of occult disease in patients with follicular lymphoma by PCR amplification of $t(14 ; 18)$ both pre- and post-treatment. Leukemia 7: 113119.

89. Al Saati T, Caspar S, Brousset P, et al. (1989) Production of anti-B monoclonal antibodies (DBB.42, DBA.44, DNA.7, and DND.53) reactive on paraffin-embedded tissues with a new B-lymphoma cell line grafted into athymic nude mice. Blood 74: 2476-2485.

90. Deweindt C, Kerckaert JP, Tilly H, Quief S, Nguyen VC, Bastard C. (1993) Cloning of a breakpoint cluster region at band 3 q27 involved in human non-Hodgkin's lymphoma. Genes Chromosomes Cancer. 8: 149-154.

91. Rimokh R, Magaud JP, Berger F, et al. (1989) A translocation involving a specific breakpoint (q35) on chromosome 5 is characteristic of anaplastic large cell lymphoma ('Ki-1 lymphoma'). Br. J. Haematol. 71: 31-36.

92. Beckwith M, Ruscetti FW, Sing GK, Urba WJ, Longo DL. (1995) Anti-IgM induces transforming growth factor-beta sensitivity in a human B-lymphoma cell line: inhibition of growth is associated with a downregulation of mutant p53. Blood 85: 2461-2470.

93. Ben-Bassat H, Goldblum N, Mitrani S, et al. (1977) Establishment in continuous culture of a new type of lymphocyte from a "Burkitt like" malignant lymphoma (line D.G.-75). Int. J. Cancer. 19: 27-33.

94. Schaadt M, Diehl V, Stein H, Fonatsch C, Kirchner HH. (1980) Two neoplastic cell lines with unique features derived from Hodgkin's disease. Int. J. Cancer. 26: 723-731. 